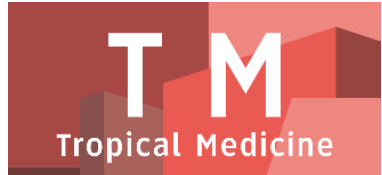

PAPER - OPEN ACCESS

\title{
Karakterisasi Nanopartikel Ekstrak Bunga Kecombrang dengan Penambahan Poloksamer
}

\author{
Author $\quad$ : Tresna Lestari \\ DOI $\quad: 10.32734 /$ tm.v1i3.275 \\ Electronic ISSN $\quad: 2623-0542$ \\ Print ISSN : :2623-0550
}

Volume 1 Issue 3 - 2018 TALENTA Conference Series: Tropical Medicine (TM)

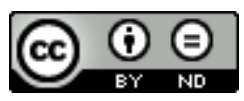

This work is licensed under a Creative Commons Attribution-NoDerivatives 4.0 International License.

Published under licence by TALENTA Publisher, Universitas Sumatera Utara
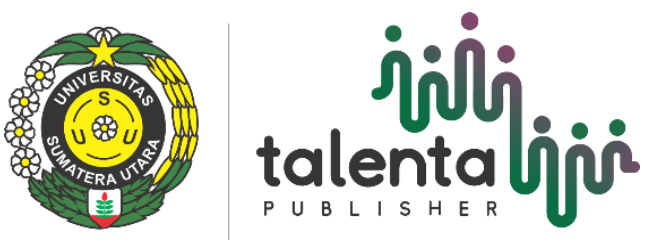


\title{
Karakterisasi Nanopartikel Ekstrak Bunga Kecombrang dengan Penambahan Poloksamer
}

\author{
Tresna Lestari ${ }^{\mathrm{a} *}$, Tita Nofianti $^{\mathrm{b}}$, Lilis Tuslinah $^{\mathrm{c}}$, Ruswanto Ruswanto ${ }^{\mathrm{d}}$, Firda Adityas $^{\mathrm{e}}$ \\ ${ }^{a b c d e}$ Program Studi Farmasi, Sekolah Tinggi Ilmu Kesehatan Bakti Tunas Husada,Tasikmalaya \\ trsnlstr@gmail.com
}

\begin{abstract}
Abstrak
Bunga kecombrang diketahui memiliki aktivitas sebagai antioksidan. Teknologi formulasi nanopartikel diharapkan dapat meningkatkan aktivitas biologis dari ekstrak.Penelitian ini dilakukan untuk memperoleh nanopartikel dari ekstrak bunga kecombrang dengan karakteristik yang baik.Pembuatan nanopartikel dilakukan dengan penambahan poloksamer dengan variasi konsentrasi 1, 3 dan 5\%. Formulasi selanjutnya dianalisis meliputi ukuran partikel rata-rata, indeks polidispersitas, potensial zeta, efisiensi penjeratan dan morfologi partikel menggunakan SEM.Hasil karakterisasi diperoleh ukuran partikel rata-rata ketiga formula berada dalam rentang 134,7-193,1 nm, indeks polidispersitas <0,5 untuk semua formula, nilai potensial zeta antara $-41,0-(-24,3) \mathrm{mV}$ dan efisiensi penjeratan terhadap senyawa flavonoid 89,93-97,99 \%. Berdasarkan hasil SEM nanopartikel diketahui berbentuk bulat dengan permukaan yang halus. Berdasarkan hasil penelitian disimpulkan bahwa nanopartikel ekstrak bunga kecombrang dengan penambahan poloksamer 1, 3 dan 5\% memiliki karakteristik yang baik dan memenuhi syarat sebagai sediaan nanopartikel.
\end{abstract}

Kata kunci: bunga kecombrang, nanopartikel, poloksamer, antioksidan.

\begin{abstract}
Ginger torch flowers extract known to have antioxidant activity. Nanoparticle formulation technology is expected to increase the biological activity of the extract. This research was carried out to obtain nanoparticle of ginger torch flower extract with good characteristics. Nanoparticle formulation was carried out with poloxamer in various concentrations 1, 3 and 5\%. The formulation was then analyzed for its particle size, polydispersity index, zeta potential, entrapment efficiency and morphological form by SEM.The characterizations obtained that particle size of all formulas were ranged from 134.7-193.1 nm, polydispersity index $<0.5$ for all formulas, potential zeta were $-41.0-(-24.3) \mathrm{mV}$ and entrapment efficiency against flavonoid content were 89,93-97,99\%. Based on SEM analysis, the nanoparticle shows to have round form with soft surface. It is concluded that nanoparticle formulation of ginger torch flower extract using poloxamer 1, 3 and $5 \%$ give good characteheristics and fulfill the condition as nanoparticle formula.
\end{abstract}

Keywords: ginger torch flower, antioxidant, nanoparticle, poloxamer

\section{Pendahuluan}

Etlingera elatior merupakan tanaman rempah yang tergolong ke dalam famili Zingiberacea dan dikenal dengan nama kecombrang. Bagian bunga dari tanaman inisering digunakan sebagai bumbu untuk berbagai jenis masakan Nusantara seperti pecel, urap dan lodeh. Disamping sebagai penambah cita rasa masakan, bunga kecombrang juga telah banyak diteliti aktivitasnya. Hasil pengujian menunjukkan bahwa ekstrak etanol bunga kecombrang memiliki aktivitas terhadap berbagai bakteri gram positif dan gram negatif [1]. Ekstrak metanol bunga kecombrang memberikan aktivitas terhadap Bacillus cereus, $P$. aeruginosa, Escherichia coli, Salmonella typhimurium, Listeria Monocytogenes dan Aeromonas hydrophila[2]. Selain itu, minyak atsiri bunga kecombrang juga menunjukkan adanya penghambatan pertumbuhan terhadap bakteri Staphylococcus epidermidis, Staphylococcus aureus dan Pseudomonas aeruginosa[3].

Sebagai antioksidan, bunga kecombrang telah diketahui aktivitasnya berturut-turut untuk ekstrak metanol, etanol dan asam asetat dengan $\mathrm{IC}_{50} 19,919 \mu \mathrm{g} / \mathrm{ml} ; 36,810 \mu \mathrm{g} / \mathrm{ml}$ danIC $C_{50} 23,233 \mu \mathrm{g} / \mathrm{ml}$ [4]. Hasil pengujian secara in vivo diketahui pemberian 2 $\mathrm{mg} / \mathrm{mL}$ ekstrak metanol dapat meningkatkan aktivitas SOD sebesar $1,3183 \mathrm{U} / \mathrm{mL}$ yang signifikan terhadap kontrol normal $(1,1159 \mathrm{U} / \mathrm{mL})$ dan kontrol negatif $(1,0178 \mathrm{U} / \mathrm{mL})$ [5]. Ekstrak etanol bunga kecombrang juga dilaporkan memiliki aktivitas sitotoksik terhadap sel HeLa [6]. Hasil uji sitotoksisitas yang lain menyebutkan bahwa ekstrak etil asetat bunga kecombrang memiliki aktivitas penghambatan terhadap sel CEM-SS dan MCF-7 dengan nilai IC $\mathrm{IC}_{50} 4 \mathrm{mg} / \mathrm{ml}$ dan $6,25 \mathrm{mg} / \mathrm{ml}$ [7].

Sediaan obat berbasis herbal seringkali dianggap kurang efektif karena aktivitasnya yang lemah dan lambat. Untuk mengatasi hal tersebut perlu dilakukan aplikasi teknologi formulasi pada sediaan obat herbal, diantarnya dengan membuat sediaan obat 
herbal menggunakan ekstrak berukuran nanopartikel. Sediaan nanopartikel dapat meningkatkan absorpsi obat sehingga lebih cepat bersirkulasi dalam darah. Ukuran partikel

yang diperkecil dalam ukuran nano akan meningkatkan luas permukaan kontak dengan demikian internalisasi partikel ke dalam membran lipid bilayer akan semakin efisien [8].

Diantara cara pembuatan nanopartikel adalah dengan menggunakan polimer yang hidrofil seperti polietilen glikol (PEG), poloxamine, poloxamer, dan polisakarida untuk menghasilkan suatu awan dinamik hidrofilik dan rantai netral pada permukaan partikel yang dapat mengusir protein plasma. Polimer hidrofilik ini dapat dikonjugasikan pada permukaan nanopartikel dengan cara mengadsorpsikan surfaktan pada permukaan nanopartikel atau dengan menggunakan kopolimer [9].

\section{Bahan dan Metode}

Bunga kecombrang diperoleh dari sekitar Kabupaten Tasikmalaya, n-Hexana (Bratachem), metanol (Bratachem), aqua deion, metanol pa (Bratachem), poloxamer Synperonic ${ }^{\circ}$ PE/P84 (Sigma Aldrich), kuersetin (Sigma Aldrich).

Ekstraksi simplisia dilakukan dengan cara refluks. Sebanyak $200 \mathrm{~g}$ simplisia diekstraksi dengan pelarut n-heksan dengan tiga kali pengulangan. Residu selanjutnya diekstraksi kembali dengan metanol sebanyak tiga kali pengulangan. Ekstrak encer yang diperoleh dikumpulkan dan dipekatkan menggunakan rotavapor.

Nanopartikel dibuat dengan menggunakan hidrasi film-tipis. Ekstrak dan polimer dilarutkan masing-masing di dalam metanol. Setelah larut sempurna, kedua zat dicampurkan sampai homogen kemudian metanol diuapkan dengan menggunakan hair-dryer sampai terbentuk lapisan film-tipis yang jernih.

Lapisan film tipis yang telah terbentuk kemudian dihidrasi dengan menggunakan air deionisasi bersuhu $50 \pm 1{ }^{0} \mathrm{C}$. Proses hidrasi dilakukan dengan cara menambahkan $50 \mathrm{~mL}$ air deionisasi berusuhu $50 \pm 1{ }^{\circ} \mathrm{C}$ kedalam lapisan film-tipis lalu dibiarkan selama 10 menit agar proses hidrasi berjalan sempurna. Setelah itu, dilakukan pengadukan dengan kecepatan 500 rpm selama 1 jam. Suhu dijaga pada $50 \pm 1{ }^{\circ} \mathrm{C}$ selama proses hidrasi hingga selesai pengadukan. Setelah proses pengadukan selesai, dilakukan penyaringan dengan menggunakan membran filter berukuran $0,2 \mu \mathrm{m}$, kemudian dilakukan evaluasi dan distribusi ukuran partikel. Konsentrasi poloxamer yang digunakan dalam tahapan ini adalah 1\%, 3\%, dan 5\%.

Pengujian karakteristik nanopartikel dilakukan terhadap ketiga formula untuk mengetahui ukuran partikel rata-rata, indeks polidispersitas, zeta potensial, efisiensi penjeratan terhadap kadar flavonoid dan morfologi partikel.

Uji efisiensi penjeratan dilakukan dengan cara nanopartikel ekstrak bunga kecombrang ditimbang sebanyak 5 ml ditambahkan $5 \mathrm{ml}$ dapar alkali borat $\mathrm{pH}$ 9,7. Kemudian sentrifugasi selama 30 menit dengan kecepatan $3500 \mathrm{rpm}$, supernatan diambil $1 \mathrm{ml}$ ditambah reagen $\mathrm{AlCl}_{3}$, natrium asetat, metanol dan dicukupkan dengan aquadest. Kemudian diinkubasi selama 30 menit. Serapan larutan tersebut diukur dengan spektrofotometer UV-Vis pada panjang gelombang $434 \mathrm{~nm}$ dan dihitung kadarnya dengan menggunakan persamaan kurva kalibrasi menggunakan standar kuersetin. Hasil dihitung sebagai flavonoid bebas.

$$
\text { Efisiensi penjeratan }=\frac{\text { flavonoid total }- \text { flavonoid bebas }}{\text { flavonoid total }} \times 100 \%
$$

Pengukuran kadar flavonoid dilakukan dengan cara sebanyak $50 \mathrm{mg}$ nanopartikel ekstrak metanol bunga kecombrang dilarutkan dalam $50 \mathrm{~mL}$ metanol. Diambil $1 \mathrm{ml}$ tambahan $3 \mathrm{~mL}$ metanol, ditambahkan 0,2 $\mathrm{ml} \mathrm{AlCl}_{3} 10 \%$, tambahkan 0,2 ml kalium asetat, dan dicukupkan dengan aquadestilata sampai $10 \mathrm{ml}$, simpan 30 menit pada tempat gelap dengan suasana suhu kamar, absorbansinya di ukur pada spektrofotometri UV-Vis dengan panjang gelombang $434 \mathrm{~nm}$. Larutan sampel dibuat dalam tiga kali replikasi sehingga kadar flavonoid yang diperoleh sebagai ekuivalen kuersetin.

\section{Hasil dan Pembahasan}

Bunga kecombrang yang digunakan dalam penelitian dikumpulkan dari beberapa tempat di wilayah Kabupaten Tasikmalaya. Sampel yang digunakan dipilih berupa bunga yang telah mekar dan berwarna merah. Bunga segar selanjutnya diolah hingga diperoleh simplisia kering melalui proses sortasi basah, pencucian, perjangan, pengeringan dan sortasi kering. Proses pengeringan simplisia dilakukan dengan cara di oven pada suhu $40{ }^{\circ} \mathrm{C}$.

Simplisia kering diuji mutunya terhadap beberapa parameter berdasarkan Farmakope Herbal. Hasil pengujian beberapa karakteristik mutu simplisia disajikan pada Tabel 1. Berdasarkan hasil pemeriksaan, simplisia yang digunakan telah memenuhi syarat yang ditetapkan Farmakope Herbal 2011.

Simplisia selanjutnya diekstraksi secara refluks bertingkat menggunakan pelarut n-heksana dan metanol. Proses ekstraksi bertingkat dipilih karena dalam bunga kecombrang terdapat kandungan lemak dan minyak yang cukup tinggi (10,81\%) sehingga dapat mengganggu penarikan senyawa aktif oleh metanol[2]. Lemak dan minyak lainnya yang berukuran besar dapat menjadi penghalang minyak atsiri atau senyawa fenolik ke dalam sel karena tidak dapat melewati dinding sel [10]. 
Tabel 1. Hasil karakterisasi simplisia

\begin{tabular}{lll}
\hline & Tabel 1. Hasil karakterisasi simplisia & \\
Parameter & Nilai & Farmakope Herbal 2011 (\%) \\
& Rata-rata (\%) & $\leq 10$ \\
Kadar Air & $5,00 \pm 0,0000$ & $\leq 10,6$ \\
Kadar Abu Total & $8,97 \pm 0,0100$ & $\leq 4,7$ \\
Kadar Abu Tidak Larut Asam & $1,40 \pm 0,1365$ & $\leq 10$ \\
Susut Pengeringan & $7,75 \pm 0,0076$ & $\geq 11,6$ \\
Kadar Sari Larut Air & $22,43 \pm 0,1266$ & $\geq 16,5$ \\
Kadar Sari Larut Etanol & $23,04 \pm 0,0300$ & \\
\hline
\end{tabular}

Dengan ekstraksi bertingkat dapat dilakukan pengurangan kandungan lemak dan minyak dalam bubuk tanaman. Lemak dan minyak dapat diekstraksi dengan menggunakan pelarut yang sifatnya non polar seperti eter minyak bumi dan heksana [11]. Residu yang diperoleh selanjutnya diekstraksi kembali dengan pelarut yang lebih polar sehingga akan diperoleh ekstrak yang berturut-turut hanya mengandung senyawa nonpolar, semipolar dan polar saja.Ekstrak yang diperoleh kemudian ditetapkan kandungan metabolit sekundernya secara kualitatif dan diperoleh hasil seperti pada Tabel 2. Di dalam ekstrak terdapat kandungan senyawa metabolit sekunder yang diduga dapat memberikan aktivitas biologis baik sebagai antibakteri, antikanker, antioksidan, dll.

Pembuatan nanopartikel dilakukan terhadap ekstrak dengan metode hidrasi film tipis menggunakan penambahan kopolimer poloksamer. Pada penelitian ini digunakan poloksamer dengan merk dagang Synperonic ${ }^{\circledR}$ PE/P84. Poloksamer dapat membentuk misel dalam medium berair di atas konsentrasi misel kritik (KMK). Pembentukan misel terjadi secara spontan dipengaruhi oleh konsentrasi polimer dan temperatur sistem [12].

Tabel 2. Hasil Skrining Fitokimia Simplisia dan Ekstrak Bunga Kecombrang

\begin{tabular}{|c|c|c|}
\hline \multirow{3}{*}{ Kandungan Senyawa Kimia } & \multicolumn{2}{|c|}{ Hasil } \\
\hline & \multirow{2}{*}{ Simplisia } & Ekstrak \\
\hline & & Metanol \\
\hline Alkaloid & + & + \\
\hline Flavonoid & + & + \\
\hline Tanin & + & + \\
\hline Polifenol & + & + \\
\hline Saponin & - & - \\
\hline Kuinon & + & + \\
\hline Steroid & - & - \\
\hline Triterpenoid & - & - \\
\hline \multicolumn{3}{|l|}{ Monoterpenoid dan } \\
\hline Seskuiterpenoid & + & + \\
\hline
\end{tabular}

Keterangan : (+) positif (-) negatif

Pada pembuatan nanopartikel dilakukan dengan variasi konsentrasi poloksamer 1, 3 dan 5\% (b/v) dan 1 g ekstrak untuk masing-masing larutan poloksamer. Nanopartikel yang diperoleh selanjutnya dikarakterisasi untuk mengetahui ukuran, indeks polidispersita dan nilai zeta potensialnya. Selanjutnya sampel dikeringkan dengan metode freeze dryer dan diuji kembali dengan menggunakan SEM (Scanning Electron Microscope) untuk mengidentifikasi morfologi permukaan, bentuk, serta ukuran nanopartikel yang ditampilkan melalui sebuah gambar.

Uji efisiensi penjeratan dilakukan terhadap senyawa flavonoid dengan mengukur flavonoid bebas dalam nanopartikel dibandingkan terhadap flavonoid total dalam ekstrak. Hasil pengujian diperoleh kadar flavonoid total dalam ekstrak sebesar $8,23 \%$ (b/b) yang ekuivalen terhadap kuersetin sebagai standar yang digunakan.

Tabel 3. Hasil Karakterisasi Nanopartikel

\begin{tabular}{ccccc}
\hline$\%$ Poloxamer & Polidispersitas & $\begin{array}{c}\text { Ukuran } \\
(\mathrm{nm})\end{array}$ & Potensial zeta $(\mathrm{mV})$ & $\%$ Penjeratan \\
\hline $1 \%$ & 0,370 & 165,1 & $-24,3$ & 89,932 \\
$3 \%$ & 0,488 & 193,1 & $-36,1$ & 97,998 \\
$5 \%$ & 0,587 & 134,7 & $-41,0$ & 96,998
\end{tabular}

Berdasarkan hasil karakterisasi terlihat bahwa karakteristik nanopartikel yang dihasilkan cukup baik pada ketiga variasi konsentrasi poloksamer. Seluruh formula memberikan partikel dalam range nanopartikel (<1000 nm) yaitu 134,7-193,1 
nmdengan stabilitas yang cukup baik (nilai potensial zeta $-41,0-(-24,3) \mathrm{mV}$ ) dan persen penjeratan terhadap senyawa flavonoid yang tinggi 89,93-97,99\%). Karakterisasi SEM dilakukan pada nanopartikel dengan konsentrasi poloksamer 5\% yang memiliki ukuran partikel paling kecil $(134,7 \mathrm{~nm})$ dan stabilitas paling baik (potensial zeta $-41,0 \mathrm{mV}$ ) dan efisiensi penjeratan mencapai $96,998 \%$. Hasil karakterisasi SEM menunjukkan permukaan partikel halus dan berbentuk sferis (Gambar 1).

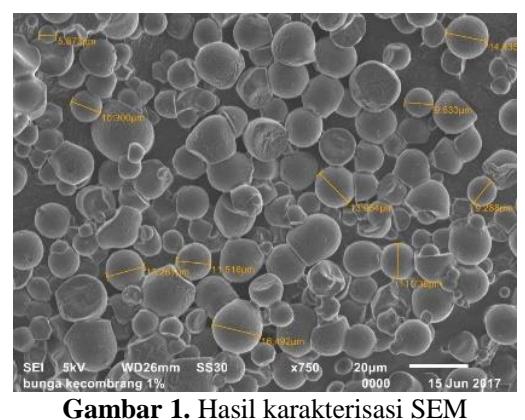

Dengan demikian formula nanopartikel yang dihasilkan dapat digunakan untuk pengembangan formula lebih lanjut. Namun demikian, perlu dilakukan pengujian terhadap aktivitas dari nanopartikel yang dihasilkan baik secara in vitro maupun in vivo.

\section{Kesimpulan}

Berdasarkan hasil penelitian di atas dapat disimpulkan bahwa nanopartikel ekstrak bunga kecombrang dengan penambahan poloksamer 1, 3 dan 5\% memiliki karakteristik yang baik dan memenuhi syarat sebagai sediaan nanopartikel.

\section{Ucapan Terima Kasih}

Pada kesempatan ini, tim peneliti mengucapkan terimaksih kepada Kemetrian Riset dan Teknologi atas bantuan dana penelitian yang diberikan melalui hibah Penelitian Produk Terapan pendanaan tahun 2017 serta STIKes Bakti Tunas Husada atas segala bantuannya sehingga penelitian ini berjalan dengan lancar.

\section{Daftar Pustaka}

[1] Valianty, K., 2002. Potensi Antibakteri Minyak Bunga Kecombrang,Skripsi, Jurusan Teknologi Pertanian, Fakultas Pertanian, Universitas Jenderal Soedirman, Purwokerto.

[2] Naufalin, R., Jenie, B.S.L. Kusnandar, F., Sudarwanto, M., Rukmini, H., 2005. Aktivitas Antibakteri Ekstrak Bunga Kecombrang Terhadap Bakteri Patogen dan Perusak Pangan. Jurnal Teknol dan Industri Pangan, Vol. XVI, No. 2 : 119-125.

[3] Pardosi F., 2012. Uji Aktivitas Antibakteri Minyak Atsiri dan Ekstrak Etanol dari Bunga Kecombrang (Nicolaia speciosa Horan) Terhadap Bakteri Staphylococcus epidermidis, Staphylococcus aureus dan Pseudomonas aeruginosa,Skripsi, Fakultas Farmasi Universitas Sumatera Utara, Medan.

[4] Lestari, A., 2014. Uji aktivitas antioksidan ekstrak bunga kecombrang (Etlingera elatior (Jack) R.M.Sm.) dengan variasi pelarutpolar terhadap radikal bebas DPPH (1,1-diphenyl-2-picrylhidrazyl), Skripsi, Program Studi S1 Farmasi. STIKes Bakti Tunas Husada, Tasikmalaya.

[5] Lestari, T., H.A. Faridah., R.Y. Lisnawati., N.D. Yanti., N. Hergiani, Ms. Rochmatin., 2016. Aktivitas Ekstrak Metanol Bunga Kecombrang (Etlingera elatior (Jack) R.M.Sm) Terhadap Enzim Superoksida Dismutase (SOD) Tikus Jantan Galur Sprague dawley. Seminar Nasional Kefarmasian Islam Ke-6. Universitas Islam Bandung. 142-150.

[6] Mackeen, M.M., Ali, A.M., El-Sharkawy, S.H., Salleh, K.M., Lajis, N.H., Kawazu, K., 1997. Antimicrobial and cytotoxic properties of some traditional Malaysian vegetables (ulam). Int. J. Pharmacogn,35, 174-178.

[7] Habsah, M., Lajis, N. H., Sukari, M. A., Yap, Y. H., Kikuzaki, H., et al., 2005. Antitumor-promoting and cytotoxic constituents of Etlingera elatior. Malays J Med Sci, Janury 12 (1) : 6-12.

[8] Won J., M.H. Oh., J.M. Oh., M.S. Kang., J.H. Choy., and S. Oh., 2008. Stability Analysis of Zinc Oxide-Nanoencapsulated Conjugated Linoleic Acid and Gamma-Linolenic Acid. Journal of Food Science, 73(8),39-43.

[9] Mohanraj, VJ., Y. Chen., 2006, Nanoparticles - A Review.Trop J Pharl Res, 5(1), 561-573.

[10] Kanazawa A., Ikeda T, Endo T, 1995, A novel approach to made of action on catioani biocides : morphological effect on antibacterial activity. $J$ Appl Bacteriol,78,55-60.

[11] Houghton, P.J. dan Raman, A., 1998. Laboratory Handbook for the Fractionation of Natural Extracts. Chapman and Hall. London.

[12] Fusco, S., A. Borzacchiello, P.A. Netti, 2006. Perspectives on : PEO-PPO-PEO Triblock Copolymers and their biochemical applications.J. Bioact Compat Pol, 21, 149-164. 